\title{
EFEKTIVITAS ANALGETIK EKSTRAK ETANOL AKAR ALANG-ALANG (Imperata cylindrica L.) PADA MENCIT PUTIH JANTAN
}

\author{
${ }^{1}$ Dewi Kartika, ${ }^{2}$ Veronika Yuliyani Gultom, ${ }^{3}$ Andelila Supriati \\ Sitompul \\ Institut Kesehatan Medistra Lubuk Pakam \\ e-mail: dewikartikafarm@gmail.com \\ DOI : https://doi.org/10.35451/jfm.v2i2.374
}

\begin{abstract}
:
Pain is an unpleasant sensory and emotional experience due to tissue damage, either actual or potential or described in the form of damage. Provision of therapeutic doses of analgesics relieve pain or suppress. Plants Imperata cylindrica empirically used as traditional medicine. The purpose of this study to know the analgetic effect of root ethanol extract of Imperata cylindrica. This study was done by infra red (IR) plantar test method with a wavelength of $96 \mathrm{~nm}$. Twenty male mice were divided to four groups. Three groups were given ethanol extract of Imperata cylindrica branches at a doses of $15 \mathrm{mg} / \mathrm{kg} \mathrm{bb}, 30 \mathrm{mg} / \mathrm{kg} \mathrm{bb}$ $60 \mathrm{mg} / \mathrm{kg} \mathrm{bb}$ and one group was given 0,5\% CMC Na (control) orally. After that, the time (second) hold infra red induction of pain every 10 minutes to 60 minutes. The data obtained were processed using one-way ANOVA and followed test the level of $95 \%$. The results of phytochemical screening Imperata cylindrica is alkaloid, flavonoid, and steroid/triterpenoid. Ethanol extract Imperata cylindrica dose of $15 \mathrm{mg} / \mathrm{kg} \mathrm{bb}$ average induction able to withstand pain of 12,$86 ; 14,34 ; 15,44 ; 19,2 ; 17,52 ; 15,42$ second, the dose of $30 \mathrm{mg} / \mathrm{kg}$ bb 13,$6 ; 17,08 ; 19,82 ; 18,44 ; 16,9 ; 16,48$ second, and a dose of $60 \mathrm{mg} / \mathrm{kg} \mathrm{bb}$ 16,$96 ; 18,9 ; 18,94 ; 22,14 ; 18,0 ; 17,26$ second.
\end{abstract}

Keywords: Analgesics, Imperata cylindrica L , Plantar test infra red.

\section{PENDAHULUAN}

Berbagai tumbuhan di Indonesia yang dimanfaatkan secara tradisional untuk penanggulangan masalah kesehatan salah satunya ialah akar alang-alang (Imperata cylindrical $L$ ). Penggunaan obat tradisional sudah menjadi kebiasaan di kalangan masyarakat dan berkembang sangat pesat. Obat tradisional banyak digunakan untuk menjaga kesehatan dan banyak diminati karena harganya yang tidak terlalu mahal dan ketersediaannya yang terjangkau bagi masyarakat terutama di desa atau kota kecil yang jarang terdapat pusat kesehatan. Dibandingkan obat modern, obat tradisional memiliki beberapa kelebihan yaitu efek sampingnya relatif rendah.

Analgetik non-narkotik adalah obat bekerja pada saraf perifer dan sentral sistem saraf pusat dengan cara menghambat pembetukan prostaglandin sehingga sensitas reseptor rasa sakit dapat berkurang. Efek samping dari obat ini yaitu gangguan lambung dan usus oleh obat golongan salisilat, penghambat prostaglandin (NSAID) dan derivat-derivat pirazolon, kerusakan darah (parasetamol, salisilat, derivat-derivat antranilat, dan derivat-derivat pirazolon), kerusakan hati dan ginjal (parasetamol, dan derivatderivat antranilat), alergi pada kulit. Efek samping tersebut terjadi terutama dalam penggunaan obat jangka panjang dan juga dosis tinggi (Tan \& Rahardja, 2007).

Alang-alang (Imperata cylindrica L.) termasuk kedalam famili tumbuhan Gramineae atau Poaceae. Tumbuhan ini tumbuh liar dimana saja tanpa dimanfaatkan dan lebih sering dianggap 
sebagai tanaman pengganggu. Tanaman alang-alang (Imperata cylindrica L.) sebenarnya memiliki banyak khasiat. Akar, rimpang dan bunga alang-alang adalah bagian yang bisa digunakan untuk pengobatan.

Berdasarkan penelitian Mulyadi, dkk (2013) menunjukkan bahwa akar, daun dan bunga alang-alang berpotensi dalam menghambat pertumbuhan bakteri Escherichia coli, Pseudomonas aeroginosa, Bacillus subtilis dan Staphylococcus aureus. Hasil penelitian Elysa (2014) rebusan rimpang alang-alang konsentrasi $30 \%$, 40\% dan 50\% menghasilkan efek diuretik pada menit ke 90 pada mencit. Bahkan telah dilakukan juga penelitian mengenai pengaruh pemberian ekstrak alkohol akar ilalang terhadap suhu tubuh pada tikus putih jantan oleh Chairul (2000) yang menyebutkan bahwa pemberian ekstrak alkohol akar ilalang dosis $50 \mathrm{mg} / \mathrm{kg}$ bb dapat memberikan efek antipiretik setara dengan pemberian paracetamol $200 \mathrm{mg} / \mathrm{kg}$ bb. Dari hasil skrining fitokimia Seniwaty (2009) menunjukkan bahwa tumbuhan alangalang positif mengandung metabolit sekunder seperti alkaloid dan flavonoid. Flavonoid berpotensi untuk mengurangi rasa nyeri dengan menghambat kerja enzim siklooksigenase (Safwan dkk., 2016).

Berdasarkan uraian diatas, akar alangalang (Imperata cylindrica L.) mempunyai kandungan flavonoid yang diharapkan dapat dijadikan sebagai obat baru dalam pengobatan analgetik.

\section{METODE}

Jenis penelitian ini adalah eksperimen semu (quasi eksperimental) dengan menggunakan desain Control Group Design. Desain penelitian ini adalah two group dengan pre test - post test. Dalam penelitian ini pengukuran dilakukan sebelum dan sesudah perlakuan untuk melihat pengaruh pemberian ekstrak akar alang-alang pada mencit putih jantan yang telah di induksi plantar test infra red.

\section{Alat}

Alat-alat gelas laboratorium, timbangan, mikroskop, termometer, kurs porselin, cawan penguap, kandang mencit, plantar test, oral sonde, spuit, lumpang dan stamper.

\section{Bahan}

Akar alang-alang, natrium karboksimetil selulosa (CMC Na), etanol 70\%, aquadest, bismuth (III) nitrat, kalium iodide, anaftol, asam nitrat, asam sulfat, besi (III) klorida, timbal (II) asetat, natrium hidroksida, asam klorida, kloroform, natrium sulfat dan asam asetat.

\section{Pembuatan Ekstrak Akar Alang-Alang}

Akar alang-alang dicuci hingga bersih kemudian ditiriskan, dirajang tipis dan ditimbang, diperoleh berat basah $5 \mathrm{~kg}$. Selanjutnya diletakkan di dalam lemari pengering, dan di atur suhunya $\pm 40^{\circ} \mathrm{C}$. Setelah kering diblender hingga menjadi serbuk, ditimbang lalu dimasukkan kedalam wadah botol plastik bertutup rapat dan disimpan pada suhu kamar. Hasil yang diperoleh digunakan untuk skrining fitokimia.

Serbuk simplisia dimasukkan ke dalam wadah maserasi sebanyak 500 gram, lalu ditambahkan 75 bagian pelarut etanol, lalu ditutup. Dibiarkan selama 5 hari dan terlindung dari cahaya matahari. Selama proses perendaman sesekali diaduk, lalu diserkai dan diperas. Ampas dari hasil perasan direndam kembali dengan cairan penyari secukupnya, kemudian didiamkan lagi selama 2 hari. Maserat di uapkan atau dipekatkan pada suhu $40^{\circ} \mathrm{C}$ didalam rotary evaporator hingga diperoleh ekstrak kental.

\section{Pembuatan suspensi CMC Na. 0,5\%.}

Taburkan 500 mg Natrium CMC. secara merata ke dalam lumpang yang berisi air suling panas sebanyak $35 \mathrm{ml}$, kemudian diamkan 15 menit hingga diperoleh massa yang transparan, lalu gerus hingga 
terbentuk gel. Kemudian diencerkan dengan sedikit air, masukkan kedalam labu tentukur $100 \mathrm{ml}$, lalu di cukupkan dengan air suling sampai garis tanda.

\section{Pembuatan suspensi ekstrak etanol akar alang-alang dosis $15 \mathrm{mg} / \mathrm{kg}$ bb, $30 \mathrm{mg} / \mathrm{kg}$ bb, $60 \mathrm{mg} / \mathbf{k g}$ bb}

Ditimbang sebanyak $15 \mathrm{mg}, 30 \mathrm{mg}, 60$ mg ekstrak etanol akar alang-alang. Digerus masing-masing dengan penambahan suspensi CMC Na. 0,5\% sampai homogen, masukkan kedalam labu tentukur ukuran $10 \mathrm{ml}$, dicukupkan dengan suspensi CMC Na. 0,5\% hingga mencapai garis tanda.

\section{Penyiapan Hewan Uji}

Sebanyak 25 ekor mencit putih jantan, dibagi dalam 5 kelompok. Sebelum pengujian hewan percobaan di aklimatisasi dan harus dirawat dengan sebaik-baiknya. Hewan yang sehat ditandai dengan pergerakan yang lincah.

\section{Prosedur Pengujian Efek Analgetik}

Hewan percobaan dipuasakan makan selama \pm 18 jam, minum tetap diberikan. Hewan percobaan ditimbang, dibagi menjadi kelompok kontrol negatif dan kelompok uji. Masing-masing kelompok terdiri dari 5 ekor mencit. Untuk kelompok kontrol negatif diberi CMC Na 0,5\% sebanyak 0,1 ml/20 gr bb. Pada kelompok uji, masing-masing hewan percobaan diberi zat uji dengan dosis yang sesuai sebanyak $0,2 \mathrm{ml} / 20 \mathrm{gr}$ bb secara oral. Setelah pemberian zat uji, hewan uji dimasukkan kedalam chamber plantar test yang telah di tentukan besar intensitas infra red nya dan di ukur pada menit 10 , 20, 30, 40, 50 dan 60. Lalu plantar instrument infra red di posisikan dibawah chamber tersebut. Ketika sudah ada gerakan dari hewan uji, maka plantar instrument akan berhenti dan plantar instrument akan menunjukkan pada waktu keberapa hewan uji tersebut kepanasan dan bergerak.

\section{Analisis Data}

Data yang diperoleh dianalisis dengan uji Kolmogorov Smirnov untuk melihat distribusi data dan dianalisis dengan uji Levene untuk melihat homogenitas data. Jika data terdistribusi normal dan juga homogen, dilanjutkan dengan uji Analysis of Vrience (ANOVA) satu arah dengan kepercayaan $95 \%$ sehingga dapat diketahui apakah perbedaan yang diperoleh bermakna atau tidak. Jika terdapat perbedaan bermakna, lanjutkan dengan melakukan uji Least Square Difference (LSD) untuk melihat perbedaan antar kelompok perlakuan bermakna atau tidak bermakna. Uji yang digunakan jika data tidak terdistribusi normal adalah uji statistik non parametrik yaitu Kruskal Wallis, selanjutnya dilakukan uji Post Hoc Test untuk melihat perbedaan yang bermakna. Analisis ini menggunakan program SPSS (Statistical Product and Service Solution) versi 20.

\section{HASIL DAN PEMBAHASAN}

Metode plantar tesinfra red (IR) yang digunakan dalam percobaan ini merupakan salah satu metode pengujian analgetik. Alasan digunakan tiga macam dosis dalam penelitian ini adalah untuk melihat apakah terdapat hubungan antara dosis dan efek hasil percobaan. Jika suatu bahan uji memberikan hubungan dosis efek, artinya makin besar dosis yang diberikan, semakin besar efeknya. Respon nyeri setelah diinduksi panas infra red pada mencit ditunjukkan dalam bentuk menjilat kaki.

Analisis dilakukan dengan cara membandingkan waktu yang dibutuhkan hewan uji untuk menahan induksi panas dari infra red (IR) $96 \mathrm{~nm}$, setelah pemberian ekstrak etanol akar alang-alang dan Na-CMC. Waktu dicatat selama 60 menit dapat dilihat pada Tabel 1. 


\section{Hasil}

Tabel 1. Hasil waktu rata-rata respon mencit menahan induksi panas infra red (IR) tiap 10 menit selama 60 menit

\begin{tabular}{|c|c|c|c|c|c|c|}
\hline \multirow[t]{3}{*}{ Kelompok } & \multicolumn{6}{|c|}{ Waktu Perlakuan Menit Ke- } \\
\hline & 10 & 20 & 30 & 40 & 50 & 60 \\
\hline & \multicolumn{6}{|c|}{ Rata-rata Respon Nyeri (detik) } \\
\hline $\mathrm{Na}-\mathrm{CMC} 0,5 \%$ & 7,18 & 8,2 & 7,6 & 8,5 & 7,3 & 6,8 \\
\hline EEAAA $15 \mathrm{mg} / \mathrm{kg}$ bb & 10,8 & 13,3 & 14,4 & 18,2 & 17,2 & 15,2 \\
\hline EEAAA $30 \mathrm{mg} / \mathrm{kg}$ bb & 13,6 & 17,5 & 15,8 & 19,4 & 16,4 & 16,1 \\
\hline EEAAA $60 \mathrm{mg} / \mathrm{kg}$ bb & 15,9 & 17,9 & 17,9 & 20,1 & 17,0 & 17,2 \\
\hline $\begin{array}{l}\text { As.Mefenamat } 500 \\
\mathrm{mg} / \mathrm{kg} \text { bb }\end{array}$ & 20,5 & 22,3 & 22,7 & 24,0 & 20,4 & 19,6 \\
\hline
\end{tabular}

\section{Pembahasan}

Dari pengamatan waktu menahan induksi nyeri panas infra red selama 60 menit pada tabel 4.3, EEAAA dosis 15 $\mathrm{mg} / \mathrm{kg}$ bb memiliki puncak tertinggi efek analgetik pada menit ke 40 yaitu 18,2 detik, EEAAA dosis $30 \mathrm{mg} / \mathrm{kg}$ bb memiliki puncak tertinggi efek analgetik pada menit ke 40 yaitu 19,4 detik, EEAAA dosis 60 $\mathrm{mg} / \mathrm{kg}$ bb memiliki puncak tertinggi efek analgetik pada menit ke 40 yaitu 20,1 detik. Dari ketiga variasi konsentrasi, puncak tertinggi efek analgetik terlihat pada menit ke 40, dan menurun kembali secara perlahan setelah selang menit ke 10 berikut nya. Dari ketiga konsentrasi ekstrak etil asetat daun mahkota dewa memiliki daya analgetik yang lebih rendah dibandingkan dengan asam mefenamat.

Parameter yang diukur pada induksi nyeri panas adalah waktu reaksi yaitu rentang waktu antara pemberian induksi nyeri sampai terjadinya respon nyeri dari hewan percobaan. Rentang waktu ini bisa diperpanjang dengan memberikan obatobat analgetik, perpanjangan rentang waktu reaksi ini dijadikan ukuran dalam mengevaluasi aktivitas analgetik (Sirait, dkk.1993).

Hasil uji Kolmogorov-smirnov dan uji Levene, dari semua perlakuan diperoleh nilai signifikan $\mathrm{P}>0,05$ yang artinya data terdistribusi normal dan homogen. Karena data yang diperoleh terdistribusi normal dan juga homogen, maka memenuhi syarat untuk dilanjutkan uji one way ANOVA. Dari hasil uji anova diperoleh nilai signifikan $P=0,000 \quad(P<0,05)$ dari setiap perlakuan yang berarti bahwa ada perbedaan bermakna yang saling signifikan. Untuk melihat kelompok yang memiliki nilai signifikan bermakna, dilanjutkan dengan melakukan uji Post Hoc Test dengan metode LSD. Hasil uji menunjukkan tidak semua kelompok perlakuan bermakna karena pada beberapa kelompok perlakuan memiliki nilai signifikan $\mathrm{P}>0,05$.

Dari hasil uji tersebut maka dapat disimpulkan bahwa pemberian ekstrak etanol akar alang-alang dengan dosis 15 $\mathrm{mg} / \mathrm{kg}$ bb, $30 \mathrm{mg} / \mathrm{kg}$ bb, $60 \mathrm{mg} / \mathrm{kg}$ bb dapat memberikan daya analgetik terhadap mencit putih jantan yang di induksi plantar test infra red. Semakin tinggi konsentrasi ekstrak etanol akar alang-alang, maka semakin tinggi daya analgetik pada mencit putih jantan. 


\section{KESIMPULAN DAN SARAN}

\section{Kesimpulan}

Semakin tinggi konsentrasi ekstrak etanol dari akar alang-alang maka semakin besar daya analgetik yang diberikan pada hewan percobaan. Ekstrak etanol akar alang-alang memberikan daya analgetik tertinggi pada menit ke-40 dan

\section{DAFTAR PUSTAKA}

\section{Buku:}

Tan, T.H., Rahardja, K. (2007). Obat-bat Penting: Khasiat, Penggunaan, dan Efek-efek Samping. Edisi kelima. Jakarta: PT Elexmedia Komputindo Kelompok Gramedia

Tetty, S. (2015). Konsep Dan Aplikasi Relaksasi Dalam Keperawatan Maternitas. Bandung: PT Refika Adiwijaya.

Sirait, M.D., Hargono, J.R., Wattimena, M., Husin, R.S., Sumadilaga. dan Santoso, S.O. (1993). Pedoman Pengujian Dan Pengembangan Fitofarmaka, Penapisan Farmakologi, Pengujian Fitokimia dan Pengujian Klinik Pengembangan dan Pemanfaatan Obat Bahan Alam. Jakarta: Yayasan Pengembangan Obat Bahan Alam Phytomedica. Hal. 156

\section{Jurnal:}

Chairul, 2000. Pengaruh Pemberian Ekstrak Alkohol Akar Ilalang (Imperata cylindrical L.) Terhadap Penurunan Suhu Tubuh Tikus Putih Jantan. Berita Biologi Volume 5, Nomor 2.

Elysa, 2014. Rebusan Rimpang AlangAlang (Imperata cylindrica L) Memberikan Efek Diuretik Pada Mencit (Mus musculus) di menit ke 90. Jurnal Ilmiah PANNMED Vol.8 No.3, 2014.

Mulyadi, dkk. 2013. Konsentrasi hambat Minimum (KHM) Kadar Sampel Alang-alang (Imperata cylindrical) dalam Etanol Melalui Metode Difusi mengalami penurunan pada rentang 10 menit berikutnya.

\section{Saran}

Disarankan kepada peneliti selanjutnya untuk meneliti aktivitas toksis dari ekstrak etanol akar alang-alang (Imperata cylindrica L.) terhadap tikus putih.

Cakram . Jurnal Kimia Vol 1. No 1. Halaman 35-42.

Safwan, dkk. 2016. Aktivitas Analgetik Ekstrak Etanol Daun Melinjo (Gnetum Gnemon L.) Pada Mencit Putih (Mus musculus L.) Jantan. Jurnal IImiah Ibnu Sina, 1(1), 71-78, 2016.

Seniwaty, dkk. 2009. Skrining fitokimia dari alang-alang (Imperata cylindrical L. Beauv) dan lidah ular (Hedyotis corymbosa L.Lamk). Jurnal Sains dan Terapan Kimia, Vol. 3 No. 2,124 133.

\section{Artikel Online:}

American Medical Association. Pain Management (Module 2): Overview of Management Options. http://www.ama-cmeonline.com/ pain_mgmt/module02/04pharm/14_ 01.

Maree T. Smith,2004. Pain Pharmacology and Analgesia. www.eolss.net/Sample-Chapters /C03/E6-81-24.pdf.

World Health Organization. (2014). Traditional, Complementary and Herbal Medicine. [Online]. Geneva: WHO.Available from: eprints.ums. ac.id/42315/6/BAB\%20I.pdf. 